dr inz: Zygmunt Nowak

Stowarzyszenie Inżynierów i Techników

Komunikacji (SITK) 0/Poznań

\title{
Wydzielony szynowy transport miejski przyszłością rozwoju miast
}

\author{
(Materiat do artykutu przedstawiono w formie prezentacji na Międzynarodowych Targach \\ Poznańskich - Transporta 2009 - Transport Szynowy XXI wieku dla Polski.)
}

\section{Identyfikacja problemu.}

\section{Motto:}

„Kryzys jest okazja do zajęcia się dtugofalowymi problemami, przyjrzenia się od nowa utrwalonym schematom. Pozwala przyjrzeć sie od dawna pomijanym problemom, takim jak ochrona środowiska, a także transport publiczny - kwestii zaniedbanej od dziesięcioleci i nadal spychanej na margines."

/Amartya Sen: Laureat Nagrody Nobla z ekonomii, prof. Uniwersytetu Harvarda i Cambridge/

New York Review of Books nr 5 z 26 marca 2009 (s.56)

Zatłoczenie ulic samochodami w miastach jest faktem, $\mathrm{i}$ to nie tylko w Polsce. I niezależnie od czynionych wysiłków zmierzających do złagodzenia ujemnych skutków tego zatłoczenia, jego skala rośnie. Czynnikami niewątpliwym wzbudzającymi ten proces jest zarówno postępująca urbanizacja, w tym proces ,,rozlewania się" miast (sprawl urban), jak i wzrost poziomu motoryzacji.

Najdotkliwszym skutkiem zatłoczenia motoryzacyjnego jest obniżenie poziomu życia mieszkańców, a w tym przede wszystkim (oprócz hałasu i polucji) obciążenie narastającą czasochłonnością podróży. Dochodzi do sytuacji absurdalnej, kiedy pokonywanie przestrzeni miejskiej zaczyna się liczyć $w$ wiele godzin $i$ stanowić trzeci (po pracy i śnie) czlon bilansu czasu mieszkańca dużego miasta. I nietrudno zauważyć, iż czas podróży jest to czas całkowicie bezproduktywny w szerokim tego słowa pojęciu, po prostu czas stracony.

Entuzjazm, a nawet euforia jaka towarzyszyła powszechnej motoryzacji minęła raczej bezpowrotnie. Własny samochód, dwa a nawet trzy w rodzinie miały gwarantować niezależność, wygodę i znaczną oszczędność czasu w pokonywaniu miejskiej przestrzeni. Rzeczywistość okazała się być fatalna. Permanentne zatłoczenie, hałas i polucja zawładnęły ulicami i stanowią istotny element obniżającego się standardu życia w mieście. A miasta rosna, z nimi motoryzacja i problem: jak najlepiej pokonać miejską przestrzeń. Społeczeństwo w pewnym sensie przyzwyczailo się do samochodu. I wszyscy, wsiadając rano w swe stalowe rumaki, spotykają się w korkach, złorzecząc i domagając się, aby „oni” coś z tym zrobili.

Ale co?

Spróbujmy odpowiedzieć na to pytanie. Oraz podpowiedzieć jak zmienić to przyzwyczajenie.

2. Sposób na rozwiązanie problemu motoryzacyjnego zatloczenia. Alians dla transportu szynowego.

Wyjścia z tak zarysowanego impasu należy poszukiwać w sposobie szybkiego pokonywania przemieszczeń osób przede wszystkim zarówno w skali całego miasta, jak i jego zurbanizowanego otoczenia, a w tym szczególnie w kontakcie ze śródmieściem. Sposób ten według obecnej wiedzy i praktyki może zapewnić jedynie wydzielony, szybki, szynowy transport publiczny. Tylko taki rodzaj transportu może konkurować, a w niektórych cechach nawet znacznie przewyższyć właściwości indywidualnego samochodu. Głównym walorem tego rodzaju transportu jest prędkość i niezawodność, które to cechy w warunkach zatłoczenia motoryzacyjnego nabierają szczególnego znaczenia.

Doświadczenia wielu miast, zwłaszcza europejskich, poddanych procesowi intensywnej urbanizacji i motoryzacyjnej presji wskazują na skuteczność takiego rozwiązania technicznego i przestrzennego.

Znakomitym przykładem mogą być tutaj miasta niemieckie, które na szeroką skalę wprowadziły szybki transport szynowy do obsługi komunikacyjnej swych mieszkańców. Wymienić można tutaj takie miasta jak Monachium, Frankfurt czy Dusseldorf, które w skali globalnej można zaliczyć do miast średniej wielkości. Również wiele innych miast europejskich o podobnej wielkości posiada szybki transport szynowy jako główny kręgosłup swych systemów transportowych.

Zauważyć jednak należy, iż mamy tutaj do czynienia ze zróżnicowanymi rozwiązaniami. A więc może to być tradycyjny tramwaj wydzielony $\mathrm{z}$ ulicy ruchu samochodowego, bądź prowadzony odrębnym koryta- 
rzem; może to być system metra, szybkiej kolei miejskiej czy rozwiązanie niekonwencjonalne (kolej jednoszynowa, maglev etc). Zróżnicowanie to wynika ze specyfiki miasta czy aglomeracji, ukształtowania przestrzennego (struktury funkcjonalno- przestrzennej) czy możliwości pozyskania odpowiednich korytarzy dla prowadzenia systemu szybkiego transportu. Wynika z tego również zróżnicowane zapotrzebowanie na tabor, które to zapotrzebowanie winno być antycypowane przez producentów tego taboru.

Zatłoczenie motoryzacyjne miast jest zjawiskiem powszechnym, mimo kosztownych i terenochłonnych inwestycji w trasy dla samochodów. W cenę rośnie również czas ludzki i jego bezużyteczne tracenie powoduje społeczne niezadowolenie, a z drugiej strony inspiruje do podejmowania efektywnych rozwiązań transportowych.

\section{Jak to rozwiązać u nas.}

Świadomość skuteczności wprowadzenia szybkiego transportu szynowego do obsługi komunikacyjnej miasta występuje w środowisku urbanistów i specjalistów od planowania układów transportu nie od dzisiaj. Gorzej jest jednak z realizacją takiej koncepcji. Występuje tutaj kilka barier, z których na plan pierwszy występuje bariera finansowa. Ale nie jest to bariera jedyna. W społecznej świadomości silny głos ma lobby motoryzacyjne, preferujące powszechną motoryzację $\mathrm{i}$ inwestowanie $\mathrm{w}$ trasy samochodowe o wysokiej sprawności. Istotnym czynnikiem który może pokonać zauważalny opór $\mathrm{w}$ realizacji koncepcji promującej transport zbiorowy, to również społeczna akceptacja takich rozwiązań. Ale nie tylko. W sposób istotny winna się zmienić społeczna świadomość, niezbędny warunek tej akceptacji. Świadomość co do wyższości szybkiego transportu zbiorowego nad samochodem leży u podstaw wyboru środka transportu przy podejmowaniu decyzji podróży w określonych warunkach, a $\mathrm{w}$ tym $\mathrm{w}$ sytuacji permanentnego zatłoczenia motoryzacyjnego.

Przy świadomości szybkiego, niezawodnego i względnie wygodnego pokonania miejskiej przestrzeni wybór transportu szynowego jest wysoce prawdopodobny.

Przypomnieć tutaj należy, iż problematyka transportu zbiorowego leży w kompetencjach lokalnego samorządu. Innymi słowy to mieszkańcy miasta mogą, czy wręcz winni zdecydować o rozwiązaniach transportowych znakomicie poprawiających ich czasowy bilans dnia, ograniczać zmarnowany czas który może być przeznaczony na inne pożyteczne zajęcia czy wypoczynek.

Jak jednak pozyskać społeczną akceptację, kiedy kult samochodu ma wymiar wręcz transcendentalny, a poglądy użytkowników ulic są rozdarte pomiędzy budową ulic szybkiego ruchu, a polityką „do nothing” (nie rób nic).

Podstawowym argumentem dla przebudowy spolecznej świadomości i pozyskania społecznej akceptacji jest konkretny, namacalny i zauważalny przyklad. Żadne werbalne i górnolotne argumenty nie zastąpią wskazanego palcem rozwiązania: oto propozycja kierunku, który winien być realizowany, jeśli chcemy wyjść z komunikacyjnego klinczu w naszych dużych miastach, a szczególnie $\mathrm{w}$ wielkomiejskich aglomeracjach.

\section{Problem taboru dla szybkiego transportu szyno- wego}

Istotnym elementem samej koncepcji szybkiego transportu szynowego jest tabor, który odpowiednio skonstruowany zapewniałby szybkie i niezawodne przemieszczanie pasażerów. Należy tutaj podkreślić znaczenie koincydencji układu tras systemu szybkiego transportu szynowego oraz użytkowanego taboru. Głównie chodzi tutaj o parametry technicznoeksploatacyjne, jak i rozwiązania techniczne (np. współpraca koła z szyna, zasilanie, gabaryty-skrajnie etc.).

Problem właściwego taboru dla szybkiego transportu szynowego $w$ polskich miastach czeka na rozwiązanie, na spójną politykę skali kraju, zarówno ze względu na obsługę bieżących potrzeb, jak i na długofalową koncepcję. Obecną politykę w tym zakresie cechuje tzw. bieżączka, charakteryzująca się organizowanymi indywidualnie przez miasta przetargami na dostawę taboru. Zasadniczą cechą tych przetargów jest zamówienie na tabor tramwajowy, dla obsługi istniejących układów tramwaju tradycyjnego.

Wydaje się, iż można antycypować potrzeby taborowe w odniesieniu do spodziewanego rozwoju szybkiego transportu szynowego. Oferta przemysłu w tym zakresie byłaby tutaj elementem inspirującym i pobudzającym. A w szczególności chodzi o:

- Tabor dwustronny tj. umożliwiający obsługe pasażerską z obydwu krawędzi i jazdę użytkową w obydwu kierunkach. Taka konstrukcja taboru jest użyteczna zarówno z punktu widzenia elastycznego wydłużania tras (eliminacja pętli tramwajowych elementów terenochłonnych, kosztownych i usztywniających układ), jak i konstrukcji stacji (przystanków), gdzie można stosować układy wyspowe, znacznie tańsze, bardziej funkcjonalne i terenooszczędne.

- Tabor umożliwiający jego wprowadzenie na trasy kolejowe. Taka konstrukcja taboru umożliwiałaby racjonalne skojarzenie sieci miejskiej z siecią kolejowa, $\mathrm{z}$ reguły rozbudowaną $\mathrm{w}$ strefie podmiejskiej. Przykładem takiego rozwiązania jest. tzw. tramper, koncepcja opracowana dla Poznania przez SITK w Poznaniu. 
- Tabor umożliwiający jazdę na dwóch zasadach zasilania tj. taki, który mógłby prowadzić ruch przy zasilaniu a górnej sieci trakcyjnej, a w tunelu umożliwiałby jazdę przy zasilaniu z trzeciej szyny. Rozwiązanie takie miałoby istotne zalety przy znacznie szerszym, niż dotąd stosowaniu tuneli dla prowadzenia szybkiego transportu szynowego na gęsto zabudowanych obszarach śródmiejskich. Obserwując narastająca gęstość zabudowy, zawężanie czy wręcz likwidowanie planowanych dotąd korytarzy komunikacyjnych i wzrost zatłoczenia motoryzacyjnego należy liczyć się z koniecznością wprowadzania szybkiego transportu szynowego na inny (przede wszystkim dolny) poziom.

\section{Poznański Szybki Tramwaj (PST) jako przykład realizacji koncepcji szybkiego szynowego transpor- tu zbiorowego.}

Koncepcja PST powstała we wczesnych latach 70tych XX wieku i wprowadzała szybki transport szynowy do obsługi komunikacyjnej Poznania w planie przestrzennego zagospodarowania miasta. Poprzez uchwalenie tego planu stała się podstawą decyzji o podjęciu realizacji PST. Planowany układ szybkiego transportu miejskiego według ówczesnych propozycji przedstawia rys. 1

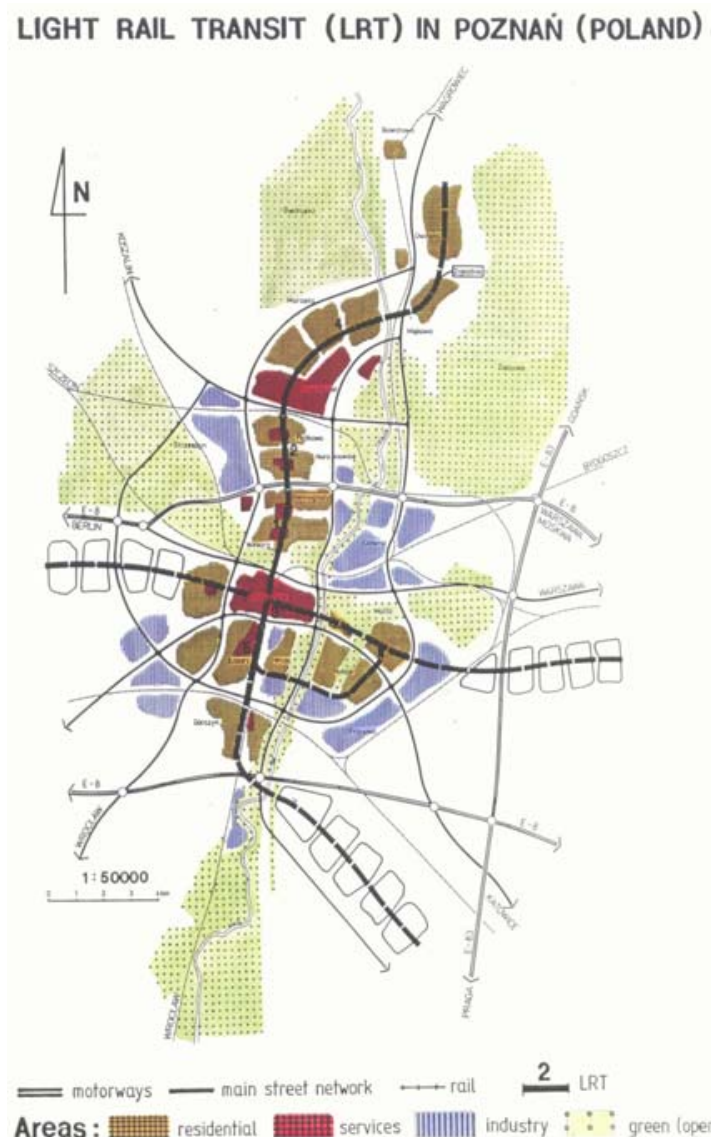

Rys. 1. Koncepcja Poznańskiego Szybkiego Tramwaju (PST). Zrealizowano pierwszy odcinek na północ od centrum w stronę dzielnic Piątkowo i Morasko
Oddany w 1997 roku do użytkowania PST stanowi przykład szybkiego, bezkolizyjnego szynowego transportu publicznego. A więc rozwiązania które można wskazać jako przyszłościowe remedium na motoryzacyjne zatłoczenie dużych miast.

12 lat użytkowania upoważniają do wyprowadzenia szeregu wniosków, w tym również w zakresie zachowań mieszkańców północnej części Poznania, obsługiwanej przez PST. Wnioski te można sformułować zarówno przez obserwacje, jak i analizy przestrzennoruchowe, a w tym analizy izochronowe.

I tak:

- Odnotować należy pełną akceptację PST przez mieszkańców Poznania, a szczególnie jego północnych dzielnic. Akceptacja ta wyraża się m.in. w zmianie ich komunikacyjnych zachowań. PST jest powszechnie wykorzystywany przy dojazdach do pracy i korzystaniu z usług. Jego szybkie powiązanie ze śródmieściem zdecydowanie preferuje ten środek transportu.

- Na uwage zasługuje lokalizacyjna atrakcyjność sąsiedztwa stacji PST, gdzie znajdują swe siedziby zarówno centra usługowe (Galeria Pestka, Centrum Biznesu Winogrady, Teslo), jak i koncentracje wysokiego budownictwa mieszkaniowego.

- Samorzutnie wokół stacji PST położonych dalej od śródmieścia wykształca się formuła „Park and Ride" (P\&R). Stosowana jest przede wszystkim przez dojeżdżających do pracy mieszkańców północnych obszarów podmiejskich. Formuła ta zaczyna się utrwalać i stanowi strukturalny element przyszłego system transportu, co należy uwzględnić w procesie planowania przestrzennego.

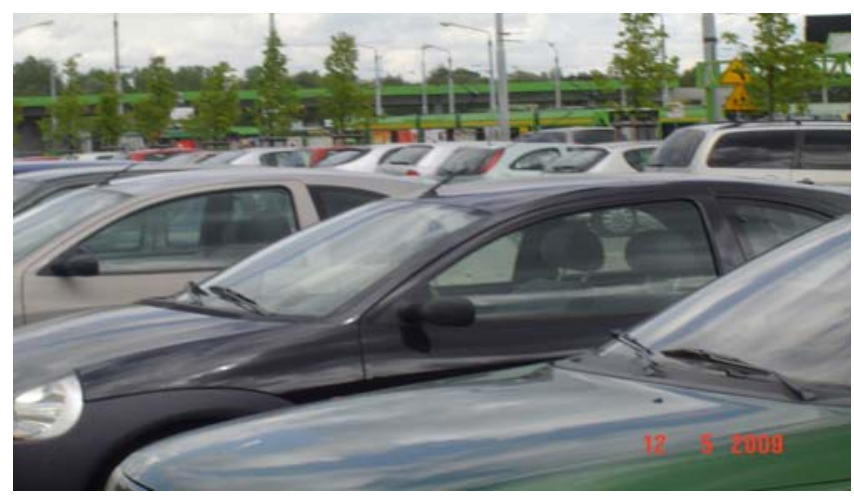

Rys. 2. Stacje PST zaczynają „obrastać” parkującymi samochodami, zwłaszcza te najbardziej od centrum oddalone. Wobec zatłoczenia ulic opłaca się („,czasowo”) zaparkować samochód i kontynuować podróż szybkim tramwajem.

- Analiza izochronowi dla północnych dzielnic Poznania wykazuje dominującą rolę PST w obsłudze tych dzielnic oraz jego wplyw na caly uklad miejskiego transportu zbiorowego. Analiza ta sporządzona w oparciu o istniejące parametry układu publicznego transportu w Poznaniu (układ tras i linii, rozkłady jazdy, częstotliwości poszczególnych 
- linii itd.) i odnosząca się do centrum miasta pokazuje jak dalece można obsługiwać północne rejony Poznania bez dodatkowych, równolegle planowanych inwestycji (rysunek).

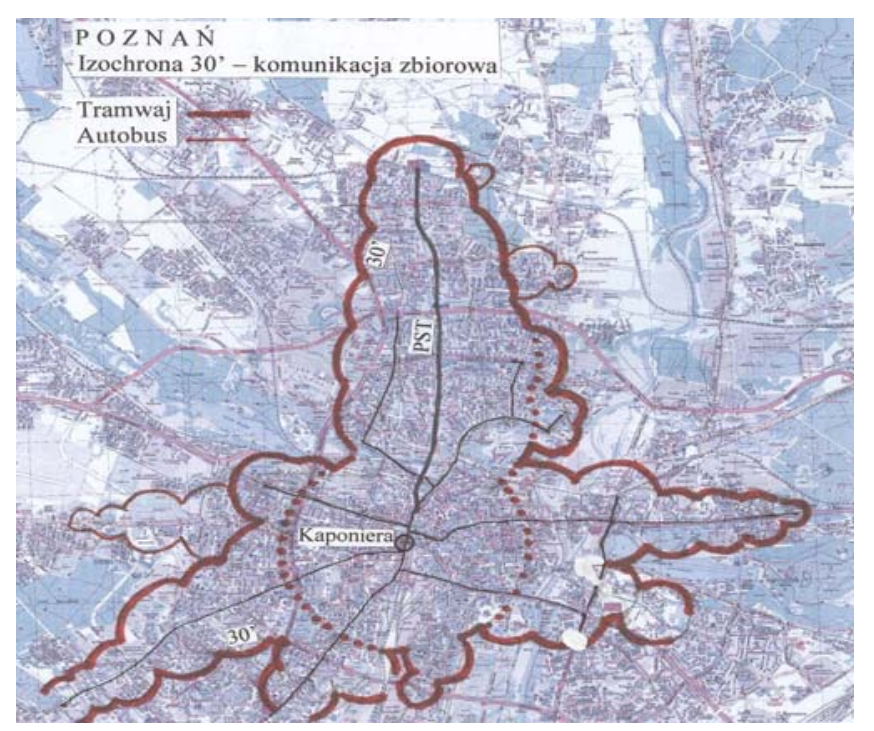

Rys.3 Półgodzinna izochrona wyznaczona dla Kaponiery centralnego punktu Poznania, komunikacją publiczną (tramwaj, autobus).

- Obecne potoki ruchu pasażerskiego (ok.5000 pas/godz. szczytu) to około $30 \%$ zdolności przewozowej PST. A mimo to obserwuje się maksymalne napełnienie taboru $\mathrm{w}$ godzinach szczytu. Paradoks ten wynika $\mathrm{z}$ faktu, iż progiem ograniczającym przewozowość trasy PST nie jest jej zdolność przewozowa, a punkt włączenia PST do sieci tramwaju tradycyjnego i wydolność tego tramwaju. Stąd wniosek, iż trasa PST nie jest w pelni wykorzystana.

- PST został zrealizowany z uwzględnieniem możliwości wspólpracy $z$ tramwajem tradycyjnym, $w$ oparciu o wspólny tabor, zaplecze itd.. Przyjąć należy, iż jest to rozwiązanie czasowe oraz iż w miarę rozwoju tego szybkiego układu trzeba uwzględnić jego wymogi, za którymi kryje się wyższy standard obsługi (prędkość, przewozowość, niezawodność itd.), i co za tym idzie, wydzielanie się tych tras $z$ układu tramwaju tradycyjnego. Istotną rolę będzie odgrywała tutaj elastyczność w przestrzennym rozwoju układu PST (np. rezygnacja ze stosowania pętli), tańsza budowa i eksploatacja peronów wyspowych (stosując tabor dwustronny) czy ograniczenia gabarytów budowli inżynierskich (przy zasilaniu z trzeciej szyny).

Poniższy schemat ilustruje zasadę budowy szybkiego transportu szynowego z czasowym wykorzystaniem systemu tradycyjnego.

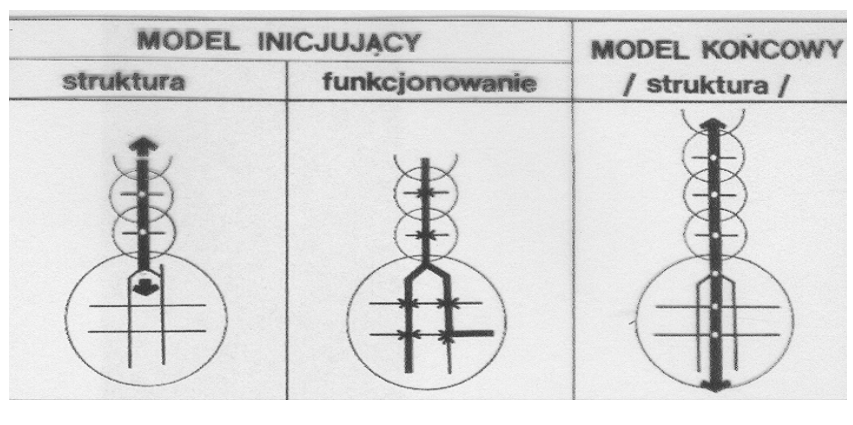

Rys. 4 Zasady wprowadzania szybkiego transportu szynowego do istniejącej sieci tramwajowej (przedstawione na modelu). Model inicjujący funkcjonuje na zasadzie wprowadzenia ruchu z trasy szybkiej na układ istniejący (obecny układ PST). Model końcowy przedstawia bezkolizyjne wydzielenie trasy szybkiej i jej połączenie z układem istniejącym węzłami przesiadkowymi lub przejazdowymi (śluzowanie).

- Wspomnieć należy, iż podejmując projektowanie trasy PST zainicjowano prace nad taborem, który mialby obsługiwać PST, ale stał się zalążkiem dla obsługi szeroko rozumianego transportu szynowego. Prace te prowadzone przez Ośrodek Badawczo - Rozwojowy Pojazdów Szynowych w Poznaniu (przekształcony później w Instytut Pojazdów Szynowych TABOR) zostały przerwane przy znacznym ich zaawansowaniu. Proponowany tabor o kryptonimie 8WE doczekał się realizacji prototypów niektórych elementów, ale wobec braku zainteresowania ze strony producentów zaniechano kontynuacji tych prac. Fakt ten odnotować należy z żalem.

- Brak lub niedoskonałość koncepcji pokonania progu związanego $\mathrm{z}$ wprowadzeniem wydzielonego szynowego transportu do obsługi miasta. Koncepcja wprowadzenia takiego rozwiązania na zasadzie całkowicie nowego podsystemu (np. metra) z góry skazuje je na niepowodzenie ze względów finansowych. Ostać się ona może jedynie w odniesieniu do dużych miast o odpowiednim potencjale finansowym i politycznym (np. metro w Warszawie).

- Konsekwencje administracyjnego podziału terenów zurbanizowanych, gdzie silnie zarysowują się konflikty, a wręcz animozje pomiędzy samorządnymi jednostkami zarządzającymi poszczególnymi obszarami. Stąd planowanie przestrzenne, a zwłaszcza systemów transportowych napotyka na utrudnienia.

- Brak „continuum” planistycznego w procesach planistycznych w skali makro (miasta, aglomeracji). Wyraża się to niekiedy całkowitym ,wywracaniem" planu zagospodarowania przy podejmowaniu prac przez nową ekipę planistyczną. W odniesieniu do miejskich systemów inżynieryjnych, 
- a szczególnie do systemu transportowego brak kontynuacji rozwiązań jest szczególnie destrukcyjny. Planowane pierwotnie korytarze dla infrastruktury (a szczególnie transportu) zostają zabudowane i trwale ograniczają możliwości realizacyjne dla tej infrastruktury.

W sprawach taboru należy oczekiwać działania długofalowego, umożliwiającego przygotowanie producentów do przedstawienia poważnych, bezkonfliktowych ofert. Dotychczasowe doświadczenia są w tym względzie raczej negatywne.

\section{Wnioski końcowe}

- Szybki transport szynowy w polskich miastach zyskał społeczne poparcie. Na przykładzie Poznańskiego Szybkiego Tramwaju (PST) wykazano, iż tego rodzaju przedsięwzięcia znakomicie poprawiają transportową obsługę miasta.
- Biorąc pod uwagę, iż za transport w mieście odpowiada samorząd, wydaje się celowe ukierunkowania tych samorządów na rzecz realizacji systemów szybkiego transportu szynowego. Winno się to odbywać się na płaszczyźnie urbanistycznej (planowania przestrzennego), koncepcji systemów szybkiego transportu szynowego, realizacji tras tego transport jak i zamówień taboru.

- Zwrócić należy uwage na rozwijający się rynek taboru szynowego w Polsce. Niestety, wielomilionowe przetargi na dostawę tego taboru zastają polski przemysł $\mathrm{w}$ sytuacji słabego przygotowania do przejmowania tych zamówień. W świetle gospodarczego kryzysu sytuacja taka winna się zmienić, na rzecz dojrzałych i zróżnicowanych ofert, na które liczą nasze miasta. 